\title{
Integrating Problem-Based Learning in a Criminal Law Course
}

\section{Dzul Rachman ${ }^{1}$, Rio Arif Pratama ${ }^{2}$, Ni Wayan Surya Mahayanti ${ }^{3}$, I Putu Indra Kusuma ${ }^{4}$}

Universitas Muhammadiyah Kalimantan Timur, Indonesia ${ }^{1,2}$

Universitas Pendidikan Ganesha, Indonesia ${ }^{3}$

Western Michigan University, United States ${ }^{4}$

Correspondence email: dzulrachman@umkt.ac.id

\section{Background:}

Abstract

In this modern era, intelligent and capable human resources to solve issues in the law field are necessary. Projectbased learning with technology integration is perhaps one of the solutions to yield such human resources. However, the previous studies did not put much attention on the implementation of technology into project-based learning. This study therefore aims to examine the effect of project-based learning on students' problem-solving ability

\section{Methodology:}

This study implemented a quantitative approach by administering a quasi-experimental design with the one group design pre-test and post-tests. This study involved 49 students who were taking a criminal law course in a university in Indonesia to obtain the data through administering tests.

Findings:

The data were then analysed by performing paired sample $t$-test analysis and showed that $t(96)=67.67, p<$ 0.001 .

\section{Conclusion:}

In conclusion, project-based learning with technology integration can enhance the students' problem-solving ability in a criminal law course. In addition, there are two implications discussed in this article.

Keywords: Project based learning; law study; schoology; problem solving

\begin{tabular}{|l|l|l|}
\hline DOI & $:$ & http://dx.doi.org/10.24903/sj.v5i1.354 \\
\hline Received & $:$ & October 2019 \\
\hline Accepted & $:$ & November 2019 \\
\hline Published & $:$ & April 2020 \\
\hline Copyright Notice & $:$ & $\begin{array}{l}\text { Authors retain copyright and grant the journal right of first publication with the } \\
\text { work simultaneously licensed under a Creative Commons Attribution 4.0 } \\
\text { International License that allows others to share the work with an acknowledgement of }\end{array}$ \\
\hline the work's authorship and initial publication in this journal. \\
\hline
\end{tabular}




\section{INTRODUCTION}

The 21st century is known as the era of information technology and globalization. Information technology and education are two rapid growing things in this modern era. Technological development is expected to support and improve the quality of education in schools. The important role Information and Communication Technologies (ICT) play in education has been increasingly recognized by educators of all levels (Rachman \& Setiawan, 2016) leading to the implementations of technology into education, including in a criminal law course.

Problem solving ability is one of the characteristics of education in the 21 st century in which problem-solving based learning approach has been being implemented in education. Problem solving based learning approaches relate to the use of intelligence from individuals who are in a group of people or the environment to solve problems that are meaningful, relevant, and contextual (Rusman, 2014; Budiharso \& Arbain, 2019). In this modern era, intelligent and capable human resources to solve problems, including those in law field, are truly needed.

With that being said, problem-based learning (PBL) is an instructional method that engages students and allows them to bring their individual assignments to the group for discussion, collaboration, and consensus (Rusman, 2014). This process is known as social constructivism, a critical framework for PBL. In PBL, knowledge is actively constructed by the learner; students are therefore not passive (Gregson, Romito, \& Garetto, 2010) where they also seek and become active in scrutinizing and constructing knowledge. Furthermore, students face alternative viewpoints by interacting with other students in small groups, thus constructing new modes of learning ( $\mathrm{N}$ et al., 2013)

PBL also offers a great tool for students' self-instruction (Lee et al. 2009) as the behavioural theory on self-regulation includes students' self-instruction as well as their responsibility for ongoing monitoring of their own progress (Mahayanti, Suprianti, Utami, \& Kusuma, 2020). The social-cognitive process constitutes both self-observation and selfjudgment that allow students to become active in their learning, especially when students are also conscious of their progress. This proof is pivotal for students, as it encourages their critical thinking, imagination, and engagement (Orsmond \& Zvauya, 2015).

As law students are mostly adult learners, these skills are particularly valuable for their development, as they are expected to solve problems and become independent the more they 
progress throughout their education (Johnsen et al., 2009). There are a lot of legal subject learning materials that the students must absorb in a relatively limited time, turning it into a lesson that is only limited to memorization without understanding the concepts that exist. In reality, this course requires many activities involving the students to solve various types of cases. However, up to these present days and according to the preliminary observation, the ability to solve problems by students has not been well developed. There were some flaws which involved the lack of ability in asking questions, answering questions, analysing arguments, looking for valid evidence (valid), and making conclusions. Therefore, problembased learning (PBL) is considered as a learning model that can solve the above issues.

A review of literature shows that PBL has increasingly been trialled and adopted across a diversity of educational institutions worldwide (Pereira et al., 2017; Wilkinson, 2014). Furthermore, problem-solving ability is one of the important abilities that students must possess. There are four phases to solve the problem. First, we have to understand the problem. Second, devise a plan to see how the various items are connected, how the unknown is linked to the data, to obtain the idea of the solution. Third, carry out the plan. Finally, look back at the complete solution, review and discuss it (Polya, 1973). Through these phases, PBL therefore contributes to developing such skills in several ways, as it asserts that learners form meaning and comprehension from their interactions both with others and through their experiences in an active learning mode (Romito \& Eckert, 2011). In line with this statement, Harmer and Stokes (2014) suggested that, in certain cases, PBL can be used as a supplementary method of instruction if teachers think that consistent use of PBL may affect the accomplishment of the learning goals. Besides, PBL is demanding in terms of planning and preparation, facilities, student discipline and monitoring and evaluating students.

Schoology is a learning management system that provides facilities that enable teachers and students to interact in a learning environment through online social networks (Jalinus \& Ambiyar, 2016). Schoology is free and allows for teacher to teacher, teacher to student, and even student to student online collaboration in a user friendly and secure environment. It offers the possibilities of adopting this collaboration and learning tools to customize learning for each student (Farmington Schoology, 2014). Through the problem-solving learning model, students independently construct their concepts with the help of various learning sources obtained online so that students are motivated to learn (Gok \& Silay, 2010). 
Furthermore, there is an increase in learning outcomes of students using schoology assisted learning (Aminoto \& Pathoni, 2014). Research repeatedly suggests that the learning that utilizes technology in the form of the web can improve students' problem-solving abilities. An educational virtual classroom environment has been defined as one that affords the potential to carry out asynchronous and synchronous learning, while problem-based learning (PBL) is used as the process to implement the planned scenarios, such as case studies, as well as to aid learning in a multidisciplinary or multi-skills context (Bignell \& Parson, 2009).

Based on the previous research, it was found that there was an increase in students' problem-solving ability after being given assignments through learning that combined face-toface learning with online learning (Ju, Mai, \& Selvaretnam, 2015). The ability to understand the relationship among concepts, maturity in reasoning, and active involvement in learning is a necessary part of solving problems. Through learning using a Problem solving, learning model through Schoology is expected to have a positive influence on students' ability to solve problems. The study would determine the differences in problem-solving skills.

However, the effect of PBL with technology integration such as Schoology on students' problem-solving ability, especially in the law field, remains unclear. The previous studies did not treat this issue in much detail. However, such information is necessary to embrace the implementation of PBL with Schoology in law courses. Therefore, this prompted us to conduct a study that aims at examining the effect of PBL with technology integration on the students' problem-solving ability.

\subsection{Research Design Selecting}

\section{METHODOLOGY}

In this study, we used the quasi-experimental method with the one group design pretest and post-test conducted at class of criminal law. According to Creswell (2012), "quasiexperiments include assignment, but not random assignment of participants to groups. This type of research uses quasi experiment (quasi experiment)". There were two variables examined, PBL with technology integration as the independent variable and students' problemsolving ability as the dependent variable. Moreover, the research design we employed was pretest post-tests control group design.

We sampled 49 law students in a university of East Borneo-Indonesia, to obtain the data. The instruments administered in this study were tests. An instrument is a tool for measuring, observing, or documenting quantitative data Creswell (2012). Creswell also 
stated that the researchers use instruments to measure achievement, assess individual ability, observe behaviour, develop a psychological profile of an individual, or interview a person. The tests we administered were the problem-solving skills tests in essay form. The valid instruments were subsequently tested before being used in research to determine the level of reliability. Based on SPPS 21 version calculations by the Cronbach alpha formula, the obtained value of the test degree of the instrument $=0.680$.

The indicators of problem-solving skills used in essay form were understanding the problem, devising a plan, carrying out the plan, and looking back. The judgment of five validators determines the validity of the instrument. The validators were four law lecturers. Based on a calculation using the equations CVR (Content Validity Ratio), the obtained result was $=1$. This result indicates that the instrument of problem-solving skills test was valid. Data were analysed using descriptive and inferential analysis respectively. The inferential analysis performed in this study was a paired sample t-test.

\section{FINDINGS}

Based on the t-test results, pretest mean is 67.67. As for the value of the Post-test, it obtained an mean of 80.94. According to the results, Pretest $67.67<80.94$ Posttest, it can be concluded that there are differences in the average test results between Pretest and Posttest which means the use of Schoology has a positive impact in teaching English in the Law Study Program.

Table 1. Descriptive Statistic

\begin{tabular}{cccccc}
\hline & \multicolumn{5}{l}{ Paired Samples Statistics } \\
\hline & Mean & N & $\begin{array}{c}\text { Std. } \\
\text { Deviation }\end{array}$ & $\begin{array}{c}\text { Std. Error } \\
\text { Mean }\end{array}$ \\
\hline \multirow{2}{*}{ Pair 1 } & pretest & 67.67 & 49 & 9.97 & 1.424 \\
\cline { 2 - 6 } & posttest & 80.49 & 49 & 8.181 & 1.169 \\
\hline
\end{tabular}

The results in this table show that the relationship between the pretest and posttest variables. Based on these results, it is found that the correlation coefficient is equal to the significance (Sig.). The value of Sig. $0.001<$ probability 0.05 , it can be said that there is a relationship between the use of schoology to the results of the posttest of Law study program students. This is also supported by the results of Paired Samples Test and Pearson Correlation. Table 2. Results of T-test

\begin{tabular}{cccc}
\hline & & pretest & posttest \\
\hline \multirow{3}{*}{ pretest } & Pearson Correlation & 1 & $.449^{* *}$ \\
\cline { 2 - 4 } & Sig. (2-tailed) & & 0.001 \\
\cline { 2 - 4 } posttest & $\mathbf{N}$ & 49 & 49 \\
\hline & Pearson Correlation & $.449^{* *}$ & 1 \\
\hline
\end{tabular}




\begin{tabular}{ccc}
\hline Sig. (2-tailed) & 0.001 & \\
\cline { 2 - 3 } $\mathbf{N}$ & 49 & 49 \\
\hline$* *$. Correlation is significant at the 0.01 level (2-tailed).
\end{tabular}

Based on the Sig (2-tailed) value, $0.001<0.05$, it means that there is a significant correlation between the use of schoology and the results of the posttest of UMKT Law study program students. The table also shows the calculated $r$ value, which is equal to 0.449 . Then the results of comparison with the value of $r$ table obtained are as follows; $r$ count $0.449>0.281$ $\mathrm{r}$ table. The conclusion that can be obtained is that there are positive impacts and significant changes from the usage of schoology after the pretest is done which results in an increase in the posttest results of students of the Law study program at UMKT. So, the use of Schoology is considered effective in teaching and improving the learning outcomes of UMKT Law study program students.

\section{DISCUSSION}

As human resources are expected to be intelligent and capable to solve real life problems with technology tools, PBL with technology integration has been proliferating in many fields of education. However, previous studies did not focus on this issue in law field. Therefore, this study aims to examine the effect of PBL with technology integration on students' problem-solving ability.

The findings in this study revealed that PBL with technology integration in a criminal law course could improve the students' problem-solving ability. To speculate, PBL is responsible for this finding where PBL is an active way for students to learn basic problemsolving skills and acquire knowledge through interaction with others, a key skill demanded by nearly every work environment. It seems that the students in this study had improved their basic problem-solving skills and led them to a better performance. Moreover, through the group's activities provided in this study, the students could improve their problem-solving skills. This finding then confirms the one found by Loyens, Kirschner, \& Paas (2011) and Bignell \& Parson (2009) that PBL represented a major development in educational practice that continues to impact courses and disciplines worldwide.

The findings also lead to a speculation that there are other potential influencing variables in the teaching and learning process. A more investigation on factors, like facilities, lecturer's strategies, and students' input were suggested. However, in this study, students who were taught with schoology were able to develop a more logic argument and were critical to particular problems. The active discussions during the online classroom helped the students to 
develop their problem-solving skill as schoology is online learning, classroom management, and social networking platform that attempts to improve learning through better communication, collaboration, and increased access to curriculum and supplemental content (Biswas, 2013). Through Schoology, students can download material that has been uploaded by the teacher in Schoology. Also, Schoology provided learning videos to attract and facilitate students in regulate their own learning. Examples of questions that will help students in forming knowledge and understanding the material as well as examples of problem-solving problems that will stimulate students to have discussions are presented in Schoology. In addition, in the material, questions that must be tried by students were provided. These ICT features can facilitate students in controlling their learning (Mahayanti et al., 2020) and also help students to become more enthusiastic in participating in learning (Gok \& Silay, 2010), because so far, as found by Kusuma, Adnyani, \& Taharyanti (2017), most students feel saturated and bored with material that is always presented through textbooks. It can develop students' knowledge and students' problem-solving abilities

The ICT-assisted problem orientation stage is using authentic problems or cases as a learning context which is presented in the form of a short video recording. At this stage students are trained to identify problems by linking basic concepts, making a list of known quantities and determining the quantities that are asked correctly. This is in line with the opinion of Khoiri (2013) who states that by presenting ICT-assisted real-world problems, students are more interested in identifying these problems.

From the above findings, there are two implications to law education that can be drawn. Firstly, it is suggested that in teaching law courses, including criminal law, PBL with technology integration should be more implemented. With this collaboration, students will be able to gain more problem-solving ability. Secondly, in implementing a PBL with technology integration, an implementation of a learning management system that can provide features for classroom assessment are necessary. To date, Schoology might be the best learning management system used by many educators around the world.

\section{CONCLUSION}

Based on the aforementioned findings and discussion, it can be concluded that PBL with technology integration is able to accommodate indicators of students' problem-solving abilities. In addition, students are also trained to think convergently by using logical-critical reasoning in considering or formulating the most appropriate answers. There are significant differences in problem solving skills between the students who learn the material of solubility 
and constant solubility product using Problem solving learning model through Schoology in the learning activities and those who learn the material.

The lecturers, including those of law course, can consider implementing the problem learning a solving schoology model to develop problem solving skills and to optimize students' learning outcomes. Furthermore, this learning model can also be applied to overcome the lack of time allocation by face-to-face learning.

\section{REFERENCES}

Aminoto, T., \& Pathoni, H. (2014). Penerapan media e-learning berbasis schoology untuk meningkatkan aktivitas dan hasil belajar materi usaha dan energi di kelas XI SMA N 10 Kota Jambi. Jurnal Sainmatika, 8(1), 13-29.

Bignell, S., \& Parson, V. (2009). Best practices in virtual worlds teaching: A guide to using problem-based learning in Second Life.

Biswas, S. (2013). Schoology-supported classroom management: A curriculum review. Northwest Journal of Teacher Education, 11(2).

Budiharso, T., \& Arbain. (2019). Teaching practice: Immersion program for teacher development profession. Asian EFL Journal. Retrieved from https://www.scopus.com/inward/record.uri?eid=2-s2.085078543752\& partnerID=40\&md5=98cdef8cfb7dfacae313c735695d56de

Creswell, J. W. (2012). Educational Research: Planning, Conducting, and Evaluating Quantitative and Qualitative Research (4th ed.). Boston, MA: Pearson.

Farmington Schoology. (2014). What is schoology. Farmington Schoology. Retrieved on November 21, 2019 from https://sites.google.com/site/farmingtonschoology/what-isschoology

Gok, T., \& Silay, I. (2010). The effects of problem-solving strategies on students' achievement, attitude and motivation. Eurasian Journal of Physics and Chemistry Education, 4(1), 7-21.

Gregson, K., Romito, L., \& Garetto, L. (2010). Students' attitudes toward integrating problem-based learning into a D.D.S. pharmacology curriculum. Journal of Dental Education, 74(5), 489-498.

Harmer, N., \& Stokes, A. (2014). The benefits and challenges of project-based learning. Plymouth University.

Jalinus, N., \& Ambiyar. (2016). Media dan sumber pembelajaran. Jakarta: Kencana.

Johnsen, D. C., Marshall, T. A., Finkelstein, M. W., \& Chalkley, Y. M. (2009). A model for critical thinking measurement of dental student performance. Journal of Dental Education, 73(2), 177-183.

Ju, H. T. Y., Mai, N., \& Selvaretnam, B. (2015). Enhancing problem-solving skills in an authentic blended learning environment: A Malaysian context. International Journal of Information and Education Technology, 5(11), 401-420.

Khoiri, W. (2013). Implementasi model problem-based learning berbantuan multimedia untuk meningkatkan kemampuan berpikir kreatif siswa kelas VII SMP Negeri 4 Kudus 
pada materi segitiga. Universitas Negeri Semarang.

Kusuma, I. P. I., Adnyani, N. L. D. S., \& Taharyanti, G. A. P. (2017). Developing 10 interesting games as alternatives to the monotonous use of flashcards for vocabulary learning and assessments. Script Journal: Journal of Linguistic and English Teaching, 2(1), 68-82.

Lee, G.-H., Tsou, K.-I., Lin, Y.-H., \& Shiau, S.-J. (2009). When a problem-based learning tutor decides to intervene. Academic Medicine, 84(10), 1406-1411.

Loyens, S. M. M., Kirschner, P. A., \& Paas, F. (2011). Problem-based learning. In K. R. Harris, S. Graham, T. Urdan, A. G. Bus, S. Major, \& H. L. Swanson (Eds.), APA educational psychology handbook, 2. Washington DC.: American Psychological Association.

Mahayanti, N. W. S., Suprianti, G. A. P., Utami, I. A. M., \& Kusuma, I. P. I. (2020). Playing with e-CALF: "Regulate My Own Learning." Advances in Social Science, Education and Humanities Research, 394, 37-42.

N, N., D, B., L, B., C, L., \& A, B. (2013). An Overview of Case-Based and Problem-Based Learning Methodologies for Dental Education. Journal of Dental Education, 77(10), 1300-1305.

Orsmond, P., \& Zvauya, R. (2015). Community of LLearners: Charting Learning in First Year Graduate Entry Medical Students during Problem-Based Learning (PBL) Study. Advances in Health Sciences Education. Theory and Practice, 20(2), 479-497.

Pereira, M. A. C., Barreto, M. A. M., \& Pazeti, M. (2017). Application of Project-Based Learning in the first year of an Industrial Engineering Program: lessons learned and challenges. Production, 27(spe). https://doi.org/10.1590/0103-6513.223816

Polya, G. (1973). How to solve it: A new aspect of mathematical method Press. New Jersey: Princeton University.

Rachman, D., \& Setiawan, I. (2016). Students' problems and experience on prezi. Script Journal: Journal of Linguistic and English Teaching, 1(2), 83. https://doi.org/10.24903/sj.v1i2.32

Romito, L. M., \& Eckert, G. J. (2011). Relationship of Biomedical Science Content Acquisition Performance to Students' Level of PBL Group Interaction: Are students learning during PBL group? Journal of Dental Education, 75(5), 653-664. https://doi.org/https://doi.org/10.1002/bmb.21046

Rusman, R. (2014). Model-model pembelajaran: Mengembangkan profesionalisme guru (2nd ed.). Jakarta: Rajawali Press.

Wilkinson, J. (2014). The Role of Project-Based Learning in Promoting Environmental Stewardship: A case study of Bahrain Teachers College. Journal of Sustainability Education, 7. 